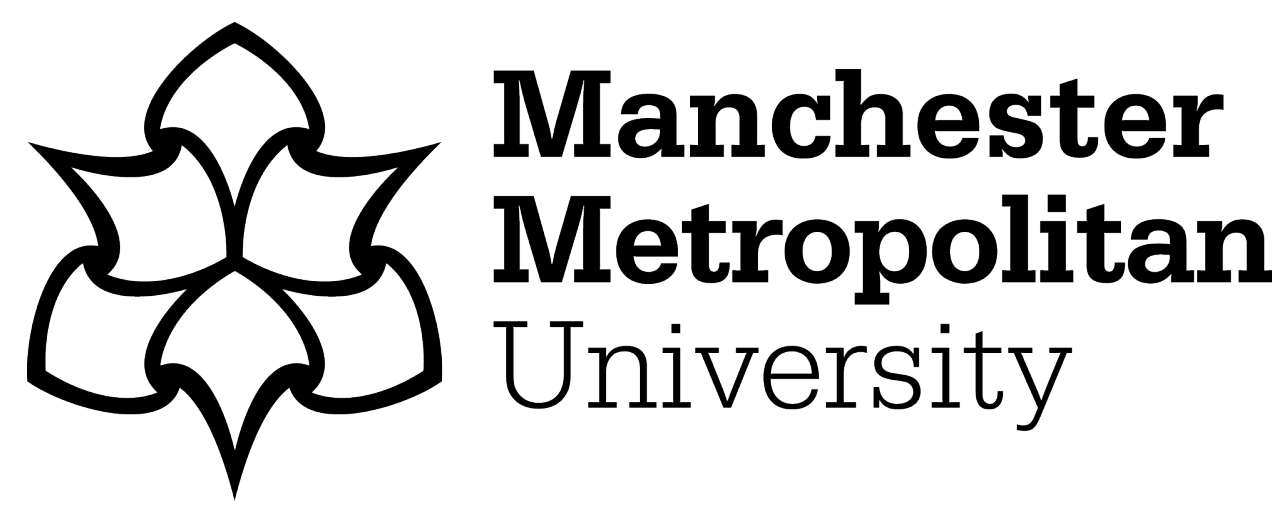

Clift, Ben and McDaniel, Sean ORCID logoORCID: https://orcid.org/00000003-2553-0836 (2017) Is this crisis of French socialism different? Hollande, the rise of Macron, and the reconfiguration of the left in the 2017 presidential and parliamentary elections. Modern \& Contemporary France, 25 (4). pp. 403-415. ISSN 0963-9489

Downloaded from: https://e-space.mmu.ac.uk/624452/

Version: Accepted Version

Publisher: Taylor \& Francis

DOI: https://doi.org/10.1080/09639489.2017.1375649

Please cite the published version 


\title{
Is this crisis of French socialism different? Hollande, the rise of Macron, and the reconfiguration of the left in the 2017 presidential and parliamentary elections
}

\author{
Ben Clift and Sean McDaniel \\ Department of Politics and International Studies, The University of Warwick, Coventry, UK
}

\begin{abstract}
With the extraordinary rise of Emmanuel Macron and the near complete collapse of the Parti Socialiste (PS), the past year has seen arguably the most dramatic upheaval in the French party system since 1958. This article develops a political economy analysis of the Hollande quinquennat to better understand how we arrived here. It argues that Hollande's programmatic failures must be situated within an institutional account of the constraints of the presidential logic of the Fifth Republic and tensions between competing factional courants within the Socialist Party. Here we shed fresh light on this moment of rupture by situating a political economy analysis of Hollande's economic programme within a more intricate institutional analysis of the specificities of the PS and its position within the Fifth Republic. The article traces the most salient political developments of the 2017 elections and outlines the political landscape of the contemporary French left. These factors explain why, after numerous crises of French socialism, this time is different.
\end{abstract}

\begin{abstract}
RÉSUMÉ
L'année passée a connu l'irrésistible ascension d'Emmanuel Macron et l'effondrement du Parti socialiste (PS), potentiellement le bouleversement le plus dramatique du système des partis français depuis 1958. Cet article développe une analyse de l'économie politique du quinquennat Hollande pour mieux comprendre comment cette situation s'est développé. II est nécessaire que les échecs du programme économique de Hollande soient situés dans un compte institutionnel des contraintes de la logique présidentielle de la Ve République et les tensions entre les courants au cœur du PS. Ensuite, l'article utilise ce compte pour tracer les développements politiques les plus profonds de la période électorale de 2017 et détaille le paysage politique de la gauche en France aujourd'hui. L'article suggère que, ce faisant, il est possible de comprendre pourquoi, après plusieurs crises du socialisme français, celle-ci est différente.
\end{abstract}

\section{Introduction}

The end of the Hollande quinquennat saw arguably the most dramatic upheaval in the French party system since the foundation of the Fifth Republic in 1958. Due to Hollande's 
deep unpopularity, for the first time in the Fifth Republic a sitting president did not run for re-election. The campaign itself saw the traditional bipolarity of the French party system shattered amidst François Fillon's corruption scandal, and under the weight of an insurgent new centrist movement led by Emmanuel Macron and populist candidates from both the far-left and far-right. Neither candidate from France's two traditional major parties made it to the second-round. Fillon, candidate of the major right-wing party Les Républicains (LR) was beaten to second place by far-right Front national candidate Marine Le Pen, whilst Benoît Hamon, of the Parti socialiste (PS) came fifth with a pitiful 6.3 per cent, eclipsed by radical leftwing populist Jean-Luc Mélenchon's 19 per cent. With the election of Macron as the country's youngest head of state since Napoleon Bonaparte, and the parliamentary majority obtained by his La République En Marche! (LRM) movement (which did not even exist 15 months before the election), France's electoral landscape has been turned upside-down.

This article focuses on the collapse of the PS and the disarray across the French left in the wake of Macron's surge. In 2012, not only did Hollande become only the second Socialist President in the Fifth Republic, but the PS earned a majority of seats in the legislative elections, giving them control over both the Assemblée nationale and the Sénat simultaneously. Yet, from its most dominant control over France's political institutions in the party's history in 2012, the PS in 2017 experienced a humiliating presidential debacle and the Socialists shed an incredible 250 seats in the parliamentary election in June. Left with a rump of just 30 députés, the PS's very existence is now in doubt. Furthermore the PS's electoral wipe-out had significant consequences for the balance of the nation's political divide. The left in France now occupies just 72 seats, compared to almost 500 for the centre, right and the far-right combined. So how did the PS fall so far so fast? And what do the results of the 2017 parliamentary election mean for the configuration of the French left?

This article develops a political economy analysis of the Hollande quinquennat to better understand how we got here. It argues that critical failures in Hollande's economic programme and governing style contributed to the contemporary parlous state of French socialism. Yet these failures must be situated within a set of longer-term institutional factors associated with the PS's internal culture and factions, its position within the French electoral landscape and the specificities of political institutions. It shows how pressures posed by the 'presidentialising' logic of the Fifth Republic, which has always caused tensions between and within the PS's competing factional courants, came to exhaust the PS's model of cohesion as developed under François Mitterrand. The rise of an insurgent centrist movement, led by a young and charismatic leader capable of attracting the PS's social democratic and 'social liberal' right-wing, has pushed French socialism to breaking point. Meanwhile Mélenchon's La France insoumise (LFI) movement represented a viable far left alternative, hell-bent on destroying the PS. Whilst the PS has experienced internal crises and significant electoral losses before, this combination of factors suggests that this time is different.

The article opens with an exploration of the organisational dynamics of the PS situated within the institutional context of the Fifth Republic and its 'presidentialising logic'. The second section provides an account of Hollande's domestic macroeconomic programme and his approach to renegotiations in the European Union, before a third section builds an account of the downfall of the Hollande administration. This analyses the long electoral campaign charting Hollande's decision not to seek re-election, the selection of Hamon as PS candidate, the rise of Macron and the late surge in support for Mélenchon's populist leftist 
LFI movement. A final section maps France's post-election political landscape, underscoring the Socialist's electoral collapse and existential fragility.

\section{Assessing the Hollande quinquennat and contemporary French Socialism}

Tensions within the PS's 'two cultures of socialism' grew during the Hollande quinquennat (McDaniel 2017). As Grunberg's (2014) account makes clear, a crisis of PS positioning within the French electoral politics has been apparent for some time. The rapidly evolving French political landscape in 2017 exacerbated these tensions, with the PS squeezed to breaking point, between a bombastic Mélenchon to its left and the 'Jupiterian' Republican monarch Macron in the centre-ground. Hollande's failures must be understood in the context of a long-run tension between reformist and revolutionary cultures of socialism within the PS (Grunberg and Bergounioux 2007), which has been exacerbated by the Fifth Republic's 'presidential logic'. This explains why the rise of Macron and his En Marche! movement was so devastating for the PS, and thus the French left as a whole.

The PS has always been an amalgamation of a number of different competing factions or courants, organised around personalities (notably potential future presidential candidates) as much as around doctrinal positions, and divided ideologically between more revolutionary and reformist elements of the socialist tradition. PS leadership requires a'synthesis' of different sensibilities to be forged into a dominant internal coalition, with each camps' policy ideas acting as the currency of internal wrangling. Although PS courants became less ideologically distinct after the 1970s, the party remained divided between its two 'cultures', between radical French socialism and the more reformist deuxième gauche ('second left') movement of Michel Rocard, closer to mainstream European social democracy in outlook and embracing the market economy and economic liberalism. For Grunberg and Bergounioux (2007, 7-9), tensions between these competing visions of French socialism created the definitional relationship at the heart of the PS as a party of government: between the ambition for governmental power, and the remorse felt by the party's left at the realities of governmental compromise. Grunberg and Bergounioux suggest three stages in the recurring cycle of French socialism's existence: a foundation (or re-foundation) characterised by asserting doctrinal orthodoxy, the compromises associated with power, and then the subsequent feeling of political failure and rejection of that governing record thereafter (Grunberg and Bergounioux 2007, 10).

Such cycles are conducive to a highly combustible political movement, and these dynamics are accentuated by the competitive dynamics of France's presidentialised party politics. Following de Gaulle's model, Fifth Republic parties approximate 'presidential machines, whose primary function is to act as a springboard for a presidential candidacy, and subsequently to act as an organizational resource for the president' (Clift 2005, 225). The PS's internal proportional representation system thus traditionally reinforced a 'presidentialised factionalism' based around its competing courants (Clift 2005, 226). Whilst the PS's factionalism is in tune with the presidential logic of the Fifth Republic, it pushed to the fore the need for uniting behind a single présidentiable. Rallying behind a candidate is one thing, but remaining united in the face of the compromises and failures of government is another. In the case of Hollande, the pressure exerted by the ambition to govern may have helped unite the Socialists in 2012, but as predicted by Grunberg and Bergounioux, the realities of power created deep divisions. Yet the contemporary crisis goes well beyond a 
period of 'remorse'. The electoral basis of the PS's governing ambitions may have collapsed. With Hollande's record unpopularity, and the rise of Macron's En Marche! movement, the social democratic'second left' has found a new political home. With their departure, the PS's hegemony on the left built by Mitterrand looks irreparably broken.

\section{Hollande's economic programme: aspirational Euro-Keynesianism meets steadfast fiscal consolidation}

Hollande came to power in 2012 proposing to move Europe away from austerity policies through renegotiating critical elements of the EU settlement, and tackling the power of global financial capitalism, which his Le Bourget speech infamously described as his 'real enemy'. These radical discursive flourishes of the 2012 campaign, and his more ambitious policy pledges, reflected the imperative of attracting leftist support. In the second-round run-off of the PS's presidential primary in 2011, Hollande needed the backing from thirdplaced king-maker, the left-winger Arnaud Montebourg, to defeat Martine Aubry. In the first round of the 2012 presidential election, Hollande reaffirmed his commitment to the antiausterity reorientation of Europe and his anti-finance declarations. Such Socialist doctrinal orthodoxy was welcomed by the PS rank-and-file. The delivery of Hollande's macroeconomic programme, however, proved extremely challenging. Hollande's radical pledges opened up a damaging and divisive gap between his campaign rhetoric and the reality of governance - a chasm which, ironically, Hollande and Lionel Jospin before him had been working hard to close since the late 1990s.

Hollande's economic strategy was premised upon significant renegotiation of European treaties, which Germany was never likely to accept. His victory was achieved amidst crisis and recession across the Eurozone, faltering French growth and rising unemployment. Following the global financial and Eurozone crises, public debt grew from around 65 per cent in the mid2000s to 89.6 per cent in 2012 (INSEE 2016a), the current deficit swelled from 2.8 per cent to 5.3 per cent between 2008 and 2012 (Eurostat 2017), and in January 2012 France experienced the downgrading of its 'AAA' sovereign bond credit rating by Standard and Poor's. Interest rate spikes fuelled fears about debt sustainability within the Hollande camp, compounded by anxieties that France's banks remained too exposed to struggling Southern Eurozone economies' sovereign debt. Consequently, alongside his anti-austerity rhetoric, Hollande prioritised fiscal consolidation throughout his election campaign in order to comply with European treaty targets, and to secure 'credibility' with both financial markets and European partners (Hollande 2011; McDaniel 2014).

There were five key aspects of Hollande's $(2012,135)$ EU proposals 'for another European politics', coalescing around a long-held Socialist ambition for a new Euro-Keynesian architecture within the eurozone. They were: the renegotiation of the new Treaty on Stability, Coordination and Governance (Fiscal Compact), the creation of 'eurobonds', a European-wide financial transaction tax (EU FTT), European banking union, and a European budget for investment. It was clear that Berlin and Brussels would reject Hollande's re-imagining and renegotiation of the Eurozone's architecture. The day after his election, both the German Chancellor Angela Merkel and Jean-Claude Juncker, then head of the Eurogroup, stated publicly that the Fiscal Compact would not be renegotiated. Sure enough, within weeks the Fiscal Compact was signed into French organic law without modification. At the same 
time, Hollande's plans for eurobonds and a real 'European investment budget' to fund future infrastructure projects fell by the wayside.

It would be unfair, however, to suggest that Hollande's European activism had no impact. Soon after arriving to power, Hollande threw his weight behind the idea of a banking union, which would not only create a single monitoring authority for European bank operations, but would pool the risk of default through a common bailout fund. Such a mechanism would effectively mutualise the cost of underwriting a crisis-ridden bank's assets, thus breaking the 'doom loop' between fragile financial institutions and over-burdened sovereigns (Clift 2018, chapter 7). Hollande's proposals contributed to the creation of the Single Supervisory Mechanism and the Single Resolution Mechanism, yet Berlin has been reluctant to pursue more ambitious measures which might expose Germany to financial risk and exacerbate 'moral hazard'. Hollande's strategic failure was to rely unrealistically upon significant European reform to enhance France's discretionary fiscal capacity. The unravelling of Hollande's European ambitions shaped the domestic macroeconomic programme of the Hollande administration, which had two distinct phases.

The first phase (2012-14) saw a front-loaded fiscal consolidation premised largely on increased taxation. Despite his anti-austerity discourse, Hollande's overriding goal was always to reduce France's deficit and debt in line with EU targets. He pledged to ambitiously cut the deficit to 3 per cent by 2013 and achieve fiscal balance by 2017, whilst ensuring 'not one euro more' in debt at the end of his quinquennat. In order to reconcile such commitments with his anti-austerity stance, initially this fiscal effort was premised upon more progressively orientated taxation increases (as opposed to spending cuts). These included cancelling $€ 29$ billion worth of niches fiscales (tax breaks), a new 45 per cent higher rate of income tax, reversing Sarkozy's relief on France's wealth tax (impôt de solidarité sur la fortune [ISF]), and, of course, a contribution exceptionnelle of 75 per cent on incomes over $€ 1 \mathrm{~m}$. Yet the strictures of an unaltered Fiscal Compact meant the Socialist administration's domestic macroeconomic programme quickly altered.

By July 2012, the government had commissioned a report on French economic competitiveness from the industrialist Louis Gallois, which underpinned the government's new 'National Pact for Growth, Competitiveness and Employment', launched in November. This Pact augured steps towards supply-side policy, its central initiative incentivising hiring through a $€ 20$ billion tax credit reducing labour charges for businesses (crédit d'impôt pour la compétitivité et l'emploi [CICE]). Building upon this early shift, a second phase of Hollande's macroeconomic programme began in earnest in January 2014 with the launch of the Pacte de Responsabilité, and lasted until the end of the quinquennat. This latter phase saw an enhanced role for liberalising supply-side reform alongside continued fiscal consolidation. Hollande's new Pacte built upon the CICE with an additional $€ 30$ billion tax cut designed to reduce the cost of labour. Consistent with its aim of fiscal tightening, however, the government pledged $\mathrm{a} € 50$ billion adjustment over the period 2015-17. Given the government's aim to shift away from increased taxation, after admitting it was'sensitive' to the so-called ras-le-bol fiscal of the French people, the character of this new fiscal effort was distinct from its earlier programme. This time, the $€ 50$ billion would come solely from spending cutbacks (OFCE 2016, 5).

In the context of low growth across the Eurozone, Hollande failed to reach his own debt and deficit economic targets, whilst unemployment increased from around 9.5 to over 10 per cent in the same period (INSEE 2016b). Significantly, moreover, the changing distributional dynamic of the Socialist administration's macroeconomic policy has had serious economic 
and political consequences. Its initial 'tax shock', the largest increase in taxation in post-war French history (Ragot 2014, 23), was responsible for slowing French economic growth by weighing on household purchasing power (OFCE 2016, 1). Yet tax cuts for business introduced since 2014 have yet to translate into significant job growth (France Stratégie 2016). This caused major political difficulties for a Socialist administration which struggled to articulate a clear or consistent vision for the economy. Fitting Grunberg and Bergounioux's model, Hollande's programmatic failings and unfulfilled election pledges were heavily criticised by the party's left. In using its fiscal marge de manœuvre to deliver tax credits for businesses, and looking to balance these measures with further spending cuts, the Socialist administration opened itself up to serious parliamentary rebellion. The frondeur movement of Socialist deputes vociferously opposed most of the government's economic and social programme from 2012. Indeed, some of the Hollande administration's most vocal opposition came from these Socialist rebels.

In this context, Hollande's failures of governing style took their toll. Inexplicably, unlike Mitterrand before him, Hollande did little to restrain party infighting. The frondeurs were constantly taking to the airwaves to decry the failings of his presidency, meanwhile Hollande's economy ministers were publicly criticising each other. Successive PS First Secretaries (party leaders), first Harlem Désir (2012-14) then Jean-Christophe Cambadélis (2014-17) did not do nearly enough to maintain party discipline. Both they and Hollande failed to secure even a minimal non-aggression pact between the president and critical voices within 'his' party. The PS as a political organisation lacked the capacity to constrain or limit these internecine excesses. It turned out that the 'synthesis' between competing factions Hollande had orchestrated and held together as party leader between 1997 and 2008 was not a firm or viable foundation for a programme of government.

Hollande's presidency could boast some achievements in labour market, pension and social policy reform (Milner in this issue), but the president never articulated a sufficiently clear governing vision. He never communicated, for example, the rationale behind and justification for the change of political economy approach from Euro-Keynesianism to supply side reforms. The fact that Hollande never effectively clamped down on ministerial infighting, combined with the cacophony of critical voices from his own parliamentary majority, added to the public's impression of discord, disorder, and a presidency lacking direction. The master of the'synthesis' lacked the requisite leadership capacities and characteristics which the French presidential Republic needs. Indeed, for all its antipathy to Bonapartism and presidentialism, perhaps the PS needs it too. The consequences of these failures of party management have been severe, posing a threat to the PS' future viability as a parti d'alternance.

\section{The end of the Hollande quinquennat: electoral collapse, reconfiguration on the left}

\section{The Socialist primary}

After years of deep unpopularity, pressure grew on Hollande throughout 2016 to renounce the opportunity to stand again as the Socialist candidate. He had pledged in 2014 he would only do so if he succeeded in reducing unemployment, which he never managed. All sitting Fifth Republic presidents had stood again, but the PS leadership organised a primary electioninitially planned to boost the legitimacy of Hollande's campaign. Despite numerous calls for 
a primary of the whole left, no agreement with the PS's major rivals, including the French Communist Party (PCF), Mélenchon and Macron, was reached. Hollande's December 2016 decision to stand aside threw the PS into flux and opened up a rancorous debate at its heart. In the absence of deference to a sitting president by his or her political family, the primary became an acrimonious fight for the future of the party between its two 'cultures'.

In an attempt to inject greater engagement into candidate selection, and thereby further embrace the 'presidential' logic of the Fifth Republic, the PS utilised an open primary for the first time in 2011. This process, which designated Hollande as the Socialist presidential candidate, was largely seen as a success for the party. The same could not be said this time around. Presidential logic pushed the PS into the primary, but, under the strain of Hollande's disastrous quinquennat, the tension inherent in the party's 'presidentialised factionalism' broke out into open warfare. Seven candidates eventually stood in the first round of the primary, none generating much enthusiasm. The courant infighting which underpins the fractious internal life of the PS shaped the competition. It bore the imprint of those PS big beasts, such as Martine Aubry, who had seen their ambitions dashed in recent years. Naturally, the primary became a contest over Hollande's bilan. The contest was dominated by Manuel Valls, Hollande's former prime minister who stood on the right of the party, and Arnaud Montebourg (former industry minister) and Benoît Hamon (former education minister), both of whom sit on the left of the party. Montebourg and Hamon had both been sacked from the government in August 2014 for criticising the rightward shift under Valls, and thus both sought to claim a rupture with the Hollande period. Valls, on the other hand, was characterised as the continuity candidate, despite his best efforts to downplay this image. In the end, the primary's second-round run-off pitted leading frondeur Hamon against Valls, with Hamon winning easily, taking 58.7 per cent of the vote against 41.3 per cent for Valls, to become the party's 2017 presidential candidate.

The electorate for the primary had shrunk, leaving a more left-wing core electoral base, which favoured Hamon (Elabe 2017). This demonstrates a weakness of the 'primary' system: particularly in instances of low voter turnout, it allows the more radical core of the party militants to choose a candidate whose programme may not appeal to the wider electorate. Secondly, the primary reveals the relative weakness and decline of the social democratic and social liberal right-wing of the PS, which had played a significant role in the party leadership and candidacies over the past decade. Organisationally the right has withered within the PS, whilst on the back of Hollande's unpopularity, the left electorate was mobilised against a 'social liberal' continuity candidate.

\section{The presidential election}

The campaign for the presidential election was the catalyst for a series of ruptures within the PS, which continued to be played out over the summer. First, the party split over support for Hamon and his programme. While Valls initially undertook to back Hamon, by the end of March he had thrown his weight behind Macron. By this time, however, other prominent social liberal PS figures had already left or were leaving what they saw as a sinking ship, including Gérard Collomb, mayor of Lyon, and the Socialist députés Richard Ferrand and Christophe Castaner. They all formed part of Macron's 'inner circle' of advisors. More informal support for Macron over Hamon came from figures including député Christophe Caresche 
and later Jean-Yves Le Drian, then still defence minister in the Socialist government. This left Hamon and his supporters castigating the treasonous behaviour of the PS's progressiste wing.

Secondly, Macron's rise facilitated a breakdown of party competition norms that had dominated French politics since the mid-1970s when the PS overtook the PCF to become the largest party of the left. Recognising the weakness of the Socialist Party and the fractured left more generally, Hamon's strategy was to incarne an alliance between what was left of the PS support and the wider left, including Mélenchon and his LFI movement. Despite some agreements with ecologists - notably Yannick Jadot of Europe-Écologie-les Verts (EELV), Hamon's strategic failure was not to realise the futility of his aspirations for uniting the wider left. There was never a realistic chance of such an alliance. Since leaving the party in 2008, Mélenchon has been dedicated to replacing the PS, not finding common cause with its left wing. Indeed, in January 2017, he spoke of a desired 'nut-cracker' effect on the PS; with LFI to the left of the PS and Macron's En Marche! in the centre-ground, he hoped discontent with the Hollande quinquennat would squeeze the PS ideologically and electorally into insignificance. Mélenchon's programme offered a strong retort to the perceived failures of the Socialist administration to fulfil Hollande's 2012 campaign pledges. Mélenchon promised an ambitious Keynesian investment plan worth $€ 100$ billion financed through borrowing and bold redistributive measures. He also ramped up LFI's anti-EU rhetoric in underlining Hollande's failures to bring about the reforms he had promised in 2012.

Although he finished fourth, Mélenchon usurped the Socialists, taking many of its traditional leftist voters to become the left's main candidate. Mélenchon's creditable 19.6 per cent of the vote decisively eclipsed Hamon's desultory 6.3 per cent. On the other side of the coin, Macron took 24 per cent of the first-round vote, attracting the PS's more moderate, social democratic and social liberal voter base. Crucially, Macron's polling consistently suggested a 60 per cent plus showing in a potential second round run-off against Marine Le Pen. With Hamon falling in opinion polls in the weeks before the vote, the logic of the vote utile further pushed Socialist voters of both the left and the right towards Mélenchon and Macron respectively. The Socialist candidate's historic low aligned Hamon with the campaign's 'also rans'. The nut-cracker effect had, it seems, worked.

\section{The parliamentary election}

The fallout from this Socialist dismal showing was severe, with Valls describing the party as 'dead', a charge not wholly denied by the party's First Secretary, Cambadélis, who conceded that a refondation of the PS, including potentially scrapping the word 'Socialism' from its name, was necessary. In a post-mortem meeting of the PS's executive, the party abandoned unpalatable elements of Hamon's leftist programme, including the universal basic income, taxes on robots and banking super-profits, and a 'Citizen 49.3'. The PS legislative programme aligned much more closely to Macron's, and the PS leadership chose a position of 'autonomie constructive' vis-à-vis Macron, supporting the new president on certain issues but retaining a critical distance, objecting to reductions in wealth taxes and flexibilising labour market reform.

Not all embraced this stance, however, and the PS has fractured into three distinct elements. Aside from the leadership's position, a second grouping on the right, including a number of government ministers, openly supported Macron and his LRM movement for the parliamentary contest and 'jumped ship' for LRM. Some remained nominally 'Socialist' 
candidates, but caused a good deal of embarrassment to the party hierarchy by refusing to make any reference to the PS in their campaign, instead labelling their candidacy as one'in support of the presidential majority'. A third grouping, led by Hamon, totally rejected the 'macroncompatibilité' of their colleagues, both in terms of active support for the presidential majority and the PS leadership's attempt to cultivate an image of constructive engagement with Macron. Instead, the ex-presidential candidate looked to revive a union à gauche strategy to halt the rise of the new president's movement, and even openly backed non-PS candidates against official Socialist candidates who would look to support Macron's presidential majority. From both the left and the right of the PS, the traditional bond of party loyalty was being destroyed.

Cambadélis might have hoped to salvage as many seats as possible by adopting Macronfriendly candidates and policy positions, and profit from the PS's deep-seated roots in local communities, and its well-resourced campaigning machine which contrasts with LRM's lack of infrastructure, yet this tactic failed. Cambadélis approached the leaders of other parties in order to reserve up to 100 seats in order to faire barrage au Front national, but bargaining from a position of such electoral weakness, he was predictably pushed back. Moreover, any PS aspirations for 'double-ticket candidates' with LRM were quashed by two factors: money and ambition. France's state funding for parties is determined by vote share and seats, with parties receiving $€ 1.42$ per vote obtained in the first round of the parliamentary election, and around $€ 37,280$ per year for each député elected after the second round. This creates powerful disincentives for double-ticket candidacies. Yet, perhaps most importantly, Macron and LRM meant what they said about 'neither left nor right' and assiduously kept their presentational and political distance from the PS throughout. As for LFI, Mélenchon's strategy was always about annihilation of, not assimilation with, the Socialist Party.

The fragility of the PS is now all too evident, with the party returning to the National Assembly after the parliamentary election with just 30 seats, shedding 250 députés. Its firstround vote share (7.5 per cent) was the worst in the history of French socialism, going back to the foundation of the SFIO in 1905. Losses on this scale inevitably saw some significant symbolic defeats for the party, including First Secretary Cambadélis, who had held his seat in Paris for 20 years, the party's 2017 presidential candidate, Hamon, and a number of high profile ministers in the Hollande administration including Myriam El Khomri and Najat Vallaud-Belkacem. Valls retained his seat in Essonne by just 139 votes, though he was not endorsed to run under a PS ticket given his open support for Macron. Scanning the electoral map of France today reveals that the Socialists no longer possess any real regional bastions; the party no longer has a single member of parliament in former Socialist strongholds including Nord, Pas-de-Calais, and Seine-Saint-Denis, nor in the major towns of Nantes, Toulouse, Lyon and Marseille. Decades of work building local networks and power bases was largely undone in 2017 (and during the Hollande presidency more generally), and these will be difficult to rebuild.

Given the two-round logic of the parliamentary election, LFI was unable to build sufficiently on Mélenchon's showing in the presidential election and obtained 17 seats. Whilst Mélenchon dreamt of Matignon, his refusal to offer a'consigne de vote' against Marine Le Pen after the first round of the presidential election was a clear strategic error, and his cult of personality dominance of his political movement also made it hard for LFI parliamentary candidates to get heard on the campaign trail. Significantly, however, LFI did well enough to form its own parliamentary group, giving it a stronger voice in parliament and greater 
financial resources. The PCF surprised by increasing its seat share, claiming 10 députés and seemingly halting its terminal decline. With record low turn-out (just 42.64 per cent) casting a pall over all the results, Macron achieved a decisive parliamentary majority of 350 seats, including Bayrou's 42 MoDem députés, although this was less than the $400+$ seats suggested by first-round polling. Amidst the massive influx of new parliamentarians, the presidential majority's new parliamentary bloc contains 140 women (48 per cent), which Macron was quick to vaunt as 'the most gender balanced' in French history, although all the key parliamentary posts went to men.

\section{The French political landscape today}

The Socialists were decimated in the parliamentary election, and although arguably they have been here before-reduced to 53 députés in their crushing 1993 defeat-this time is different. Not only is the scale of this parliamentary defeat bigger, but the party's devastatingly poor presidential vote is unprecedented. Whilst the PS did collapse in 1993, it retained strong local electoral bases capable of helping it revive national electoral support. Moreover, Mitterrand was still president at the time, and just two years later in 1995, PS candidate Jospin received 47 per cent of the second-round vote. The political landscape around the PS has changed fundamentally in the last 12 months, and its position as France's mainstream left party no longer seems secure. For the first time since 1962, the PS is neither in government nor the main opposition party; its reign as a true parti d'alternance may have come to an end. Not only will the PS parliamentary group struggle to make its voice heard, but the PS is, more than ever, a deeply divided movement. Furthermore, the electorally crippled party cannot hope to impose discipline upon what few PS députés remain. Given that the majoritarian voting system of France's major elections punishes parties outside of the dominant two, we may have seen the end of the comforting bi-polarity that produced periodic electoral swings in the PS's favour. Furthermore, the financial implications of the 2017 election alone raise questions about the PS's ongoing viability. In the wake of its poor electoral results, the PS is set to lose around $€ 15$ million of its state aid funding. There has even been talk of the party selling its historic headquarters in the Rue de Solférino.

Immediately after the second round of the legislatives, Cambadélis resigned as First Secretary, stating that the left 'has to change everything. He paved the way for an interim direction collégiale to lead the party's renewal with its own distinct image and programme. This interim leadership team has been tasked with rebuilding the party, pursuing a'ni Macron ni Mélenchon' line, yet this will not be straightforward as the PS must redefine itself within the void created by the exit of party figureheads from both its left and right wings, and the party remains divided in (at least) three groupings. A rump of the PS will continue to limp on through the new parliament, pursuing its 'ni-ni' strategy, but the question is whether anyone will notice. The PS's social liberal right sees LRM as offering a more attractive home, and path to power, as seen in Valls's decision to quit the party in favour of sitting with the presidential majority. The left of the party argue for a more radical break with the Hollande quinquennat is necessary, evidenced in Hamon's decision also to leave the PS and form his own movement that will 'go beyond political parties'. In this endeavour, Hamon's advances made to Mélenchon have once again been rebuffed.

One of the most striking consequences of the 2017 parliamentary election is the collapse of the left altogether, and thus the demise of bipolarity in French electoral politics. Of the PS's 
30 députés, around a dozen are'Macron compatible', whilst the left-wing frondeur movement has almost been wiped out from the Socialist parliamentary group. Officially the PS opted to enter the opposition by voting against confidence in the new government of Edouard Phillippe on 4 July. Yet, revealing the party's inability to command discipline or loyalty and indicating its desire not to cause further instability, it retained the possibility of Socialist députés abstaining, an option eventually taken up by the majority of PS députés. Three députés defied the weakened PS leadership to vote with Phillippe's government.

Mélenchon has promised to provide vocal opposition to Macron's administration 'in the Assembly and in the street', and has been customarily forthright and colourful in criticising Macron's labour market reforms, described as 'El Khomri ++ law' (in reference to the contentious and unpopular labour market reform introduced under Hollande). Yet the force of this opposition to Macron is weakened by the perennially fractured composition of the French left, with the PS, LFI and the PCF choosing to remain separate from each other in their parliamentary groups. In demanding voting discipline around LFI's own programme, L'Avenir en commun, Mélenchon has retained his hostile stance towards the Socialists and once again aggravated tensions with the Communists. With seven parliamentary groups (even LR have split, with a splinter 'constructive LR' group also forming), this parliament is the most fractured of the Fifth Republic. Without a clear and forceful opposition, the political strength of Macron's majority looks to be further enhanced.

France's youngest ever president can also look forward to enjoying a political economic environment his predecessor could only have hoped for, with economic growth returning and unemployment falling. After five long years of fiscal consolidation, economic conditions within the eurozone have finally picked up, and the economic upturn could give Macron's mandate a significant boost. In addition, he will benefit from improved relations with Germany. Though rapid and significant change remains unlikely, in the context of the UK's exit from the European Union and the threat of a Le Pen victory in France the noises from Brussels and Berlin were much more positive in 2017 than in 2012. Macron has pushed immediately for a range of ambitious reforms at the EU level, all of which were put on the table by Hollande, including a eurozone finance minister and shared budget.

Yet, the next five years will not be plain sailing for Macron. Very early on, several of Macron's ministers were forced to resign. Most symbolically, after seeking to implement a projet de loi de moralisation de la vie publique, Macron forced his MoDem coalition partner, François Bayrou, to step down as Justice Minister amidst accusations of a MoDem 'fake jobs' scandal involving misused European Parliament funds. Programmatically, Macron's first governing efforts faced the familiar challenge of enacting fiscal retrenchment to meet the 3 per cent deficit target, whilst seeking to honour his campaign commitments and property and wealth tax reduction pledges. Public sector efficiency savings are the mooted means to square that circle-but we have heard that before. Flagship plans to flexibilise French labour law, to be fasttracked through the legislative process by'ordinance' rather than normal parliamentary bills, remain controversial and unpopular with unions and what's left of France's parliamentary opposition.

Furthermore, should the fractured left reconfigure and rebuild itself, the traditional bipolarising logic of France's two-round electoral system (which punished centrist forces throughout the Fifth Republic) could return at Macron's expense. It must be remembered that, despite its current dominance in parliament, the record abstention levels mean that LRM obtained a historically low 32.3 per cent of the vote ( 7.3 million votes) in the first round of the 
2017 parliamentary election. In comparison, the mainstream right lost the 2012 parliamentary election to the PS while claiming 34.6 per cent (9 million votes). Macron's new movement has achieved an extraordinary amount in an inordinately short space of time, and with it has transformed French politics. Yet, there remains much work to do to solidify its support in order to remain resilient in the face of resurgent competition from both its left and right.

\section{Conclusion}

This article has suggested that in order to understand the contemporary state of French socialism, Hollande's programmatic and party leadership failures must be situated within an understanding of longer-term institutional constraints for the PS, of factional in-fighting associated predominantly with the presidential logic of the Fifth Republic and the tension within the party between the two cultures of socialism. Although operating within an extremely difficult macroeconomic and institutional environment, Hollande's management of his own economic programme had adverse economic and political consequences. Hollande's limitations as president and party leader were exposed as the Socialist's administration's macroeconomic programme dampened the French recovery, whilst its shifting distributional dynamic favoured business over households. Understanding these failings, and situating them within an institutional account of the PS within the Fifth Republic helps explain why the PS collapsed in 2017.

Caught between LRM's self-avowed pragmatic centrism and staunchly pro-European social liberalism on the one hand, and the more radical, muscularly leftist, rhetoric and eurosceptic stance of Mélenchon's LFI, the emaciated PS is struggling to make its voice heard. In the history of the PS, only Mitterrand demonstrated the political acumen and strength to achieve an enduring synthesis between the 'first' and 'second' lefts, historically a necessity for a dominant left party within the Fifth Republic. Ultimately, the differences between these two groups have never been resolved, and Hollande's attempts to practice l'art de la synthèse et du compromis unravelled dramatically after 2012. Whilst Grunberg and Bergounioux's model predicts a period of 'remorse' after periods in government, this time it seems that the Socialist administration's failures have provoked a more significant reconfiguration on the left and the wider French party and political systems. The compromises made in power and Hollande's programmatic and leadership failings raised the traditional tensions that exist within PS factions to stratospheric levels. The PS is now struggling to continue operating after a period of near total electoral collapse, with party funds heavily diminished and seemingly no clear présidentiable ready and capable of pulling the party back from the brink. The rise of a new centrist movement led by a charismatic young leader has lured a core of the rocardienne right away from the PS. The combative LFI have laid fresh claims to the radicalleft space within French politics. This crisis of French socialism really is different, and deeper, than earlier PS debacles.

\section{Déclaration de divulgation}

Aucun conflit d'intérêts potentiel n'a été rapporté par le(s) auteur(s).

\section{Funding}

This work was supported by the Leverhulme Trust [grant number RF-2012-340]. 


\section{References}

Clift, B. 2005. "Dyarchic Presidentialization In A Presidentialized Polity: The French Fifth Republic." In The Presidentialization of Politics - A Comparative Study of Modern Democracies, edited by P. Webb and T. Poguntke, 221-245. Oxford: Oxford University Press.

Clift, B. 2018. The IMF and the Politics of Austerity in the Wake of the Global Financial Crisis. Oxford: Oxford University Press.

Elabe. 2017. "Comprendre le vote / Les primaires citoyennes." Études \& Sondages. Accessed March 19 2017. https://elabe.fr/comprendre-vote-primaires-citoyennes/, 29 January 2017.

Eurostat. 2017. "General Government Deficit (-) and Surplus (+) - Annual Data." Eurostat, [accessed here]. Accessed March 1 2017. https://ec.europa.eu/eurostat/tgm/table.do?tab=table\&init=1\&language= en\&pcode=teina200\&plugin $=1$.

France Stratégie. 2016. Comité de suivi du Crédit d'impôt pour la compétitivité et l'emploi Rapport 2016. Paris: France Stratégie, September 2016.

Grunberg, G. 2014. "Le Socialisme français en crise." Modern \& Contemporary France 22 (4): 459-471.

Grunberg, G., and A. Bergounioux. 2007. Les socialistes français et le pouvoir: L'ambition et le remords. Paris: Fayard.

Hollande, F. 2011. "Hollande interview: 'Je veux une gauche qui apaise'". Le Parisien, 15 October 2011. [accessed here:] accessed August 20 2016. https://www.leparisien.fr/election-presidentielle-2012/ candidats/francois-hollande-je-veux-une-gauche-qui-apaise-15-10-2011-1654124.php.

Hollande, F. 2012. Changer de destin. Paris: Robert Laffont.

INSEE. 2016a. 'Tableau: Dette publique au sens de Maastricht', Dette et déficit publics, Tableaux de I'Économie Française Édition 2016, INSEE, [accessed here:] Accessed May1 2017. https://www.insee. $\mathrm{fr} / \mathrm{fr} /$ statistiques/1906709?sommaire=1906743\#tableau-T14F131G1.

INSEE. 2016b. "The Unemployment Rate Was Stable in Q1 2016." INSEE, [accessed here:] Accessed April 1 2017. https://www.insee.fr/en/statistiques/2011466\#consulter.

McDaniel, S. 2014. "Post-Crisis Social Democratic Policy Capacity in France and the United Kingdom: A Lesson from the Globalisation and Social Democracy Debate." French Politics 12 (4): 283-309.

McDaniel, S. 2017. "French Socialism in Crisis: The Undoing of Hollande's 'Anti-Austerity' Programme." Renewal 25 (1): 39-52.

OFCE. 2016. 'Le Quinquennat de François Hollande : Enlisement ou Rétablissement ?', Policy Brief 2, 5 September 2016, 1-10. Paris: OFCE.

Ragot, X. 2014."Le désajustement européen." problèmes économiques: Crise, croissance et modèle social, 17-25. November 2014 special edition. Paris: La Documentation française https://www.ofce.sciencespo.fr/pdf-articles/2013/N-Special-Problemes-ecos-JECO.pdf. 